\title{
Dialogues between social and natural sciences: contribution to the debate on socio-environmental conflicts
}

\author{
BRUNO MILANEZ \\ Departamento de Engenharia de Produção e Mecânica, Universidade Federal de Juiz de Fora, Rua José \\ Lourenço Kelmer, s/n, Campus Universitário, São Pedro, 36036-900 Juiz de Fora, MG, Brasil
}

Manuscript received on January 7, 2015; accepted for publication on April 17, 2015

\begin{abstract}
In this article, I argue that attempting to solve real problems is a possible approach to bring social and natural sciences together, and suggest that - as Environmental Impact Assessment necessarily brings together social and environmental issues - this debate is a strong candidate for such a task. The argument is based on a general discussion about the possibilities and limitations of Environmental Impact Assessments, the social-environmental impacts of mining activities and three case studies. The analysis of the cases indicates possibilities and limitations of the dialogue between scientists from various areas - and of the collaboration with social movements and affected communities - in avoiding negative impacts of mining projects and, eventually, increasing their sustainability.
\end{abstract}

Key words: interdisciplinary, sustainability, social-environmental conflicts, mining.

\section{INTRODUCTION}

\section{PRELIMINARY CONSIDERATIONS}

In this article, is assumed that promoting dialogue between natural and social sciences on the challenges of sustainability comprises a double objective. First, it is necessary to motivate both natural and social scientists to look beyond their knowledge fields and seek for correspondent or complementary understanding in other areas. Second, a specific effort has to be made so that the knowledge created by this integration promotes effective social change in the quest for sustainability;

E-mail: bruno.milanez@ufjf.edu.br which means influencing governments, firms and society towards more sustainable practices.

There is a broad debate on the conditions to promote interdisciplinary research. For example, Leff (2011) focuses on resistance problems of the scientific field and their agents. At the same time, Campbell (2005) mentions the transition costs to move from one area to another, the barriers regarding financing and the difficulties in publishing interdisciplinary works in disciplinary journals. Nevertheless, their debate is beyond the scope of this article, and I adopt a more normative perspective.

Along these lines, I argue that attempting to solve real problems is a possible strategy to bring 
scientists from different areas together; assuming they share common problems. Furthermore, I suggest that, as Environmental Impact Assessment (EIA) necessarily brings together social and environmental issues, this debate is a strong candidate for the given task. In addition, attempts to ensure the social and environmental viability of economic projects are a concrete contribution to sustainability. Lastly, based on some field experience on the power inequality associated with EIA, I propose that the given quest for sustainability takes into consideration the needs of the more vulnerable groups and, whenever possible, incorporate their demands.

In order to support my arguments, this article is based on four main sections. To start off, I comment on the relevance of the cooperation between natural and social scientists for advancing knowledge. This debate brings along some specific initiatives as well as experiences from some interdisciplinary areas. Then, I describe some aspects related to EIA and explain how they could promote dialogue between the various knowledge areas. Following, I briefly comment on some general socio-environmental aspects of mining, and present three case studies associated with these activities. Based on these cases, I discuss to what extent debates between scientists - and dialogue with social movements and affected communities - might increase the degree of sustainability of mining projects. In the last section, the evidences are summarized and the main argument is defended.

The paper is mainly based on literature review. The debate on dialogue between social and environmental science, as well as the discussion on environmental impact assessment, rely on the analysis of scientific articles. The description and analysis of the case studies, however, have a more empirical perspective. Although they are mainly supported by documental research, they are also based on observations made when the author visited those areas.

\section{NATURAL AND SOCIAL SCIENCES: CREATING DIALOGUES}

In his presidential address at the Annual Meeting in 2008 of the American Political Science Association, Axelrod (2008) proposed that political scientists should attempt to exchange knowledge and information with other sciences, and used biology as an example. This proposal is just one among many exhortations for interdisciplinary research (cf. Committee on Facilitating Interdisciplinary Research and Committee on Science Engineering and Public Policy 2004).

Interactions between natural and social scientists may happen at various levels or degrees. For example, there are situations when scientists, still restricted to their knowledge area, "borrow" ideas from other sciences. For example, Axelrod (2008) mentions how Thomas Malthus' ideas influenced Darwin's Theory of Evolution, and at the same time, Darwin inspired some of Karl Marx's proposals related to the class struggle.

A second degree of interaction may take place when scientists decide to develop their research on a fringe area. Jared Diamond is a good example of this practice, seeing that in spite of his $\mathrm{PhD}$ in biophysics, most of his studies might be associated with anthropology and biogeography. One illustrative idea, presented by Diamond (2002), evaluates to what extent the shape of the continents would influence food availability for different societies. Making it simple, the author argues that "the spread of food production tended to occur more rapidly along east-west axes than along north-south axes, mainly because locations at the same latitudes required less evolutionary change or adaptation of domesticates than did locations at different latitudes". He uses this argument when trying to explain why food (e.g. wheat) dispersed quicker between Europe and Asia than along the Americas (e.g. potato and corn). As a result, people in Eurasia had access to a larger variety of edible plants than those in other continents and, he argues 
that such access is one explanation for higher population density in ancient Europe.

The third level of interaction may be identified when the collaboration among various knowledge areas bring about new research fields. There are various emergent disciplines that attempt to promote dialogue between the natural and the social sciences, such as Political Ecology, Ecological Economics, and Popular Epidemiology.

Political Ecology is a framework for comprehending the thermodynamics principle at institutional and social levels (M'Gonigle 1999). It looks at ecological distributive conflicts, i.e. conflicts involving access to environmental resources and services (Martinez-Alier 2002). Political Ecology is concerned with the burdens of impacts that arise due to inequalities in power, property and income (Gerber et al. 2009), being deeply influenced by the egalitarian tradition of political economy (Kallis et al. 2013).

Ecological Economics, on the other hand, is proposed as a strategy to provide a systemic view of environment and economy; it emerged from the "bioeconomics" of the 1970s and attempts to analyze the economic system based on biophysical and ecological concepts. Along these lines, it is based on the assumption that the economic system must be seen as part of the biophysical world, since this system depends fundamentally on energy and matter (Amazonas 2001). In other words, Ecological Economics aims at grounding economic thinking within biophysical and moral constraints (Daly and Farley 2004).

Lastly, Popular Epidemiology is defined as "citizen science", and is characterized by the use of epidemiology tools by lay people who try to identify local illness patterns and environmental stressors in order to propose strategies to alleviate suffering, particularly in heavily polluted areas. Popular Epidemiology, though, is not limited to diagnoses and statistics, and involves different understandings of well-being, health, and risk (Brown 1987, Corburn 2005).

Although these experiences might inspire some natural and social scientists to seek dialogue, they do not explain how to promote this integration in everyday research. In order to reach this aim, two complementary strategies could be used.

First, one could think about what scientists have in common. Lach (2014) remembers that scientists, in general, share an acceptance of the scientific approach, which means, investigations that are "systematic, sceptical, analytical, and ethical". In order to bring these ideas closer to sustainability, Funtowicz et al. (1998) propose that scientists should aim at enhancing "the process of the social resolution of the problem [...], rather than a definitive 'solution' or technological implementation".

This aspect might be associated to the second step: the development of research issues that bring together different disciplines. As mentioned by Costanza et al. (1991), one way to integrate many perspectives is focusing on problems rather than on tools or models to solve them. This argument goes along with Trow's (1957) idea that the problem dictates the research method, and with Lach's (2014) argument that, when dealing with a particular problem, a degree of pragmatism in choosing from multiple approaches helps conduct interdisciplinary research.

The strategies mentioned above might be used in various contexts. Public health, climate change, and hazardous products, are a few examples. In order to illustrate one of these situations, in the following section, I debate some aspects related to EIA of mining activities and describe three cases where this dialogue has, or could have, supported the pursuit of a more sustainable society. 


\section{RESULTS AND DISCUSSION}

ENVIRONMENTAL IMPACT ASSESSMENT: PRACTICES AND LIMITATIONS

EIAs, in general, attempt to bring together both social and environmental perspectives, but the implementation of EIAs is contestable. Bührs (2009) mentions that one can understand EIAs from three different perspectives. First, there is a more naïve point of view, adopted in the USA during the 1970s, which argues that EIA was "an objective and neutral instrument designed to avoid environmental deterioration". A second perspective would imply the institutionalization of environmental values within the administrative state. Lastly, a more skeptical perspective proposes that EIA serves to "legitimise actions or developments that are socially or environmentally damaging; [...] on this basis, [it] is a process for overcoming public opposition and for making projects acceptable by granting minor concessions".

The use of EIAs has been transferred from industrialized countries to peripheral ones, mainly due to incentives from international cooperation agencies, such as the Organization for Economic Co-operation and Development (OECD), the United Nations Environment Program (UNEP) and the World Bank (Rocha et al. 2005). Similarly, EIAs were promoted in Brazil in response to international pressures from foreign investors (Rohde 2006).

However, when transferred to the Global South, these instruments were adapted, becoming more pragmatic and less effective. Kirchhoff (2006) argues that EIAs in peripheral countries are different because of the lack of social demand and low priority in public policies. The author maintains that, this context created environmental agencies with limited technical capacity as well as insufficient power for implementation. According to Zhouri (2008), governments in peripheral countries adopted EIAs mainly as a strategy to legitimize environmentally questionable projects.
Thus, reports would never consider a project environmentally unfeasible; on the contrary, they would only recommend the internalization of some externalities in order to increase the acceptance of the project.

Maybe, because of multilateral agencies' influence, EIAs in Brazil have not assimilated a critical perspective, and often have assumed a pretense of objectivity. Along these lines, literature on EIA in Brazil still seems to adopt the naïve perspective identified in the USA in the 1970s.

For example, when reviewing the EIA concepts, Rocha et al. (2005) argue that EIAs would be forecast instruments, which would be capable of minimizing negative impacts of projects and activities. The authors maintain that, according to some views, the evaluations would even predict the emergent conditions of both project and alternatives. Similarly, Moreira (1985) proposes that environmental impact assessment is a group of procedures capable of ensuring a systematic evaluation of environmental impacts of an action (project, plan or policy) and its alternatives. Along the same lines, Sanchez (2006) defines the environmental impact assessment as a technicalscientific activity, developed to identify, anticipate and explain the consequences over the environment of a particular human initiative. To some extent, following this rationale, the environmental impact assessment would be closer to the cost-benefit analysis and its role would be to ponder the positive and negative social-environmental impacts of a project, and to propose preventive, corrective or compensating measures.

On the other hand, there are authors that criticize the way the EIA has been performed. For example, Cashmore et al. (2010) suggest that EIAs are arenas for pressure and negotiation, as they deal mainly with distributional justice, the satisfaction of needs and liberty. Similarly, Bührs (2009) defends that as in any other political environment, the EIA playing field is not even. Looking specifically at 
the Brazilian context, Zhouri (2008) argues that the EIA process has structural problems, since the reports are presented to society only after government and companies have agreed on the terms of the project. Along these lines, EIA has not been used to actually evaluate the environmental sustainability of projects.

Looking at the Brazilian context, authors have highlighted diverse limitations, such as inequality in influence capacity, disregard of non-Western forms of knowledge, high level of subjectivity and barriers to social involvement.

When debating EIA in Brazil, Zhouri (2008) divides problems into two groups: politicalstructural and procedural. From the politicalstructural perspective, the author argues that decision in the concession of environmental licenses is centralized, and that groups in favor of the projects have much easier access to decision makers. She concludes that this core issue is the source of most procedural problems. Along these lines, it could be argued that decision is made based on political criteria and under pressure of economic agents that would not suffer the negative impacts of the projects (Glasson and Salvador 2000, RBJA 2009). On the other hand, people against the projects or that bear their effects, have little or no access to the decision makers. In reality, publicizing EIAs would be the last stage of a long decision-making process, which has been confined to private and governmental agents. As a result, public debate would not have room for real contestation (Ebisemiju 1993, Leroy and Acselrad 2009).

This process would mean a displacement of the debate from the political to the economic realm, and the substitution of collective rights for private interests (Zhouri 2008). This type of process would turn the concession of environmental licenses into a bureaucratic ritual. It could be argued that this institutional vulnerability is the most important issue when debating EIAs' limitations.
A second issue related to EIAs has to do with the disregard of non-Western forms of knowledge. An important strategy to control the EIA and the concession of environmental licenses is the use of scientific language. Documents and reports are commonly limited to technical conceptions of nature, and are not necessarily presented in understandable language to the lay public. Therefore, agents with particular abilities - such as fluency in English, proficiency in the use of computers and internet, familiarity with project structures - have a disproportionate access to power. These capabilities, nevertheless, are restricted to a minority of society and exclude members of rural communities, ethnic minorities and poor urban households (Glasson and Salvador 2000, Laschefski 2011, Leroy and Acselrad 2009, Zhouri 2008).

Due to this overvaluation of technical aspects, EIAs might create an apparent democratic and participative image, while being restrictive in terms of those who can effectively participate. This situation creates a "knowledge monopoly", giving privileges to a few agents, undervaluing other forms of understandings and excluding specific social groups (Cashmore et al. 2010).

In addition to these problems related to the overvaluation of scientific knowledge, there are also methodological issues that have to be taken into consideration. On the one hand, it is common that EIAs emphasize quantitative measures of environmental impacts, and underestimate qualitative aspects, arguing they are more difficult to assess (Bührs 2009). On the other hand, although many EIA advocates argue that the reports consider environment in various dimensions - ecological, social and economic - studies usually present a disproportionate concern with impacts on the natural environment (Leroy and Acselrad 2009, RBJA 2009).

A third element that must be considered in the development of EIAs is the level of subjectivity. 
In spite of the scientific discourse associated with EIAs, reports might still vary depending on who prepares the studies. In this respect, Vanclay (2003) mentions that EIA studies prepared by consulting companies might differ considerably from others formulated by public research institutes or even by communities. The author maintains that each of these "versions" has a particular legitimacy and none should be considered definitive. Alternatively, the debate on each report must consider who has performed the study. Along the same lines, Bührs (2009) comments that EIA reports, mean different things for different agents, and its building is the result of the interaction of various points of view and diverse interests.

These differences between EIA versions are a result not only of interests, but also of values that guide the various social groups. The elaboration of an EIA report is a complex task and there is room for subjectivity when one decides what must be considered relevant and what might be marginal (Richardson 2005). In other words, as EIA reports attempt to call society's attention to significant impacts, defining what "significant" means depends on personal values, knowledge and ideology (Bührs 2009).

A final issue that must be considered when debating EIAs, is the barrier to social involvement. Usually, various social agents - environmental agencies, firms, consulting companies, and affected communities - get involved in the debate of large projects. Due to this diversity of interests and values, public participation is considered essential to ensure respect to the various points of view.

Nature of social participation can be quite diverse. At a more basic level, society could be invited to help the state in the decision-making process. A more intense participation could create mechanisms to ensure that society makes decision together with government agents. A third level then could redefine decision structures, ending the separation between decision makers and impacted communities. This would be the desired level of participation for EIAs, as it would promote a more equal distribution of power (O'Faircheallaigh 2010).

When proposing social participation in impact assessment of large projects Vanclay (2003) argues that "people have a right to be involved in the decision making about the planned interventions that will affect their lives". Following the same line of argument, Morrison-Saunders and Early (2008) maintain that any person whose interests may be affected by a decision should have an opportunity to be heard.

Another aspect related to public participation is related to strategies developed to involve social groups. Public hearings are the most common practice to ensure participative debates on economic projects. Nevertheless, in Brazil, there has been some distortion in the way meetings are held. Ideally, public hearings were supposed to offer an opportunity for challenging studies and reports; however, when communities are informed about projects, there is little room for questioning, once feasibility projects are almost finished (Zhouri 2008). In addition, it is common that meetings happen far from the places where affected people live, making it difficult for them to take part in the debates (RBJA 2009).

In summary, EIAs are contentious strategies to ensure and promote sustainability. Although they have been broadly adopted in various countries, their effectiveness may still be questioned, particularly in peripheral countries, like Brazil. The debate on their value in avoiding social and environmental impacts becomes specifically questionable in cases of intense environmental impacts, such as openpit mining. Some of these impacts are described in the next section; then, three case studies are discussed, in order to evaluate to what extent the dialogue between social and natural scientists might contribute to sustainability. 


\section{THE ENVIRONMENTAL IMPACTS OF MINING ACTIVITIES}

\section{Overview}

Mining is an issue that can easily bring together environmental and social debate, as this activity creates various impacts related to both nature and society. On the environmental side, one might mention changes in the landscape, air pollution, and water contamination. From the social point of view, important issues relate to community displacement and working conditions (ELAW 2010, Power 2002).

Considering the changes in landscape, there are issues like erosion and deforestation. Mining projects require large areas not only because of the mine itself, but also for the disposal of overburden and tailings, as well as for its supporting structure: concentration plants, pipelines, railroads etc. These problems become even more intense in the case of open-pit mines, which require more space and generate larger amounts of overburden than the underground ones. These changes in the landscape have specific impacts on habitat fragmentation and loss of biodiversity.

Regarding air pollution, it is necessary to consider that ore extraction is an energy intensive activity, demanding high amounts of fossil fuels. In Brazil, mining was responsible, in 2005, for $2.6 \%$ of total $\mathrm{CO}_{2}$ emissions from fossil fuels (Brasil 2010). Another important issue related to air pollution is the emission of particle matter from the mine and ore processing activities. Studying atmospheric emission is an important field to bring together nature and social scientists. First, it is important to develop mathematical models that help understand local climate, pollutant dispersion etc. Second, health scientists might try to estimate how pollution affects communities. For example, Braga et al. (2007) concluded that, in Itabira (MG), a traditional mining city, a growth of $10 \mu \mathrm{g} / \mathrm{m}^{3}$ in the amount of particular matter increased in $4 \%$ the number of children and $12 \%$ the number of teenagers taken to emergency rooms due to respiratory diseases. Lastly, social groups do not respond in the same way to changes in their environment, and understanding how social groups construct their environmental problems is a possible task for social scientists (Hannigan 1995).

Water consumption and contamination are also problems associated with mining activities. Considering consumption, it is estimated that iron ore concentration demands around $1.4 \mathrm{~m}^{3} / \mathrm{t}$ of water (Schnellrath et al. 2002). Besides that, as mines are dug down, companies need to lower the underground water bodies, impacting springs in the region. In addition, depending on the mineral, the concentration processes require toxic products, such as cyanide and mercury, or produce hazard by-products such as red sludge (a side product of the transformation of bauxite in alumina, which has high concentrations of sodium hydroxide). In Barcarena (PA), there have been two important red sludge spills (in 2005 and 2009), which polluted rivers and streams, making them unsuitable for consumption and preventing more than 100 families from fishing and watering their vegetable gardens, their main source of food (Milanez et al. 2010).

All these environmental changes cause impacts on social groups. Depending on the proximity of cities, farms or settlements, changes in the landscape, air characteristics or water quality affect public health and compromise traditional economic activities.

Mining is planned according to the ore availability. In this sense, it could be argued that mining is geologically determined and can only be performed where the ore concentration is high enough to make the extraction technically and economically feasible. This search for the largest and best reserves, often creates conflicts with current economic activities. For example, there are 330 families living in the settlement Roseli Nunes, in Mirassol D'Oeste (MT). The settlement, built in 
1997, produces food for municipal schools based on agroecology principles; therefore, the settlement provides health fresh foods without pesticides, to poor children in the municipality. However, the whole project is under risk because a reserve of 11 billion tonnes of iron ore was found under the settlement, which companies want to extract and export (Malerba 2014).

In addition to the displacement of communities and economic activities, there are also issues related to working conditions in the mines themselves. As mines are created in rural areas, there is a need for a considerable amount of laborers. As rural workers may not be qualified for the usual tasks in mines, frequently a considerable amount of personnel is brought to the regions. This migration, though, tends to rapidly increase demand for sanitation, public health, transport and other urban services for which most towns are not prepared for, causing a significant decline in the local quality of life (ELAW 2010). In addition, it is common that firms take advantage of the situation and impose precarious working conditions to laborers. For example, in 2010, Vale S.A. was fined in R\$ 300 million for social dumping, in Parauapebas (PA). There, workers took more than two hours commuting to and from the mines, but this period was neither paid nor included in the working hours (Sakamoto 2010).

Therefore, there are various potential socialenvironmental conflicts associated with mining activities. Some of them become explicit during the EIA processes, others only after the mines start operating. As the activity creates relevant changes to the environment and society, debating possible solutions for such problems is an opportunity to avoid or mitigate some of these problems.

In the rest of this section, I describe three case studies of socio-environmental conflicts associated with mining activities in the state of Minas Gerais. They represent mines in different stages of their life cycles and experiences with several levels of success as far as sustainability is concerned. The Congonhas case describes conflicts associated with an operating mine. In this example, partnership between natural scientists and social movements managed to restrict the expansion of the mine, curbing impacts to the city water supply; on the other hand, an equivalent partnership was not created to deal with air pollution. In the second case, the study of the Rio-Minas Project looks at the setting-up of a new mine in Conceição do Mato Dentro. This example shows how fragile current EIA processes in the state of Minas Gerais are. It looks at some particular social problems (land grabbing and slave labor) but also indicates how the lack of support from natural scientists made community claims on water pollution fragile. Lastly, the case study on the Serra do Gandarela considers the previous debate on the opening of a new mine and evaluates the cooperation between social and natural scientists in building a proposal for a mosaic of protected areas. Although not avoiding the mine, the project is considered a plausible alternative to reduce the negative impacts of the mining and, supposedly, increase sustainability.

\section{Congonhas}

Congonhas is a historical city in Minas Gerais; famous for its XVIII-century buildings and for art pieces by Aleijadinho, one of the masters of the Brazilian baroque. Although most of its history is related to gold mining, currently, Congonhas depends economically on iron ore. There are four large mining companies operating in Congonhas: Companhia Siderúrgica Nacional (CSN), Namisa, Vale S.A. and Ferrous Resources. The oldest and largest mine is the Casa de Pedra, which belongs to CSN and is located less than $10 \mathrm{~km}$ from the city center (Goulart 2014).

During the early 2000s, as international price of iron ore skyrocketed, CSN decided to increase ore extraction and invest more than $\mathrm{R} \$ 11$ billion in 
mine expansion and in a new pellet plant (Goulart 2014). In order to expand the mine, CSN intended to transfer its activities from the rear side of Morro do Engenho, to the front side, which faces the city.

The local community did not receive this decision well, mainly due to the negative impacts on the landscape. The front side is covered by native forest, being part of the local scenery and contributing to the city's microclimate. In addition, there are 29 springs in the area, which are responsible for $50 \%$ of the city water supply (Laguardia 2012). The relationship between water and mining is a sensitive debate in Congonhas, as studies by COPASA (the state-owned water supply company) have associated mining activities near to catchment area with a gradual decrease in water flow (Hoje em Dia 2013). Therefore, the involvement of hydrologists from COPASA was crucial in the debate on the expansion of Casa de Pedra and in curbing the increase of mining activities.

In spite of this good experience, it is not always that this kind of partnership between social movements and natural scientists has proved possible in Congonhas. Another conflict involves air pollution and emission of particulate matter, but a solution has not been found yet. Historically, social movements have complaints about air pollution events, without obtaining any concrete action from companies or local government. In general, there is an ordinary lack of evidence as companies perform uncoordinated studies, which are not effective for a proper air quality evaluation. Recently, the Office of the Public Prosecutor demanded from Ferrous Resources a broad study on air pollution, which found that air quality in areas close to the mines is inferior to the standards defined by legislation (Ferrous Resources do Brasil 2012).

This situation seems to be particularly critical in Bairro Pires. This is a rural neighborhood that is closer to the mine. Households from Bairro Pires claim that, in the last years, health problems such as asthma and bronchitis have become more common.
Nevertheless, the municipality and the firms neither acknowledge these claims, nor perform epidemiological studies in the area. Therefore, this could be an opportunity for a new partnership between natural scientists, health practitioners, social scientists and community, to evaluate the impact of air quality on public health, but such links still have to be created.

\section{Conceição do Mato Dentro}

Conceição do Mato Dentro is a tiny town, with only 18 thousand inhabitants, and whose economy is based on small-scale agriculture, ranching and tourism. It is located $150 \mathrm{~km}$ from Belo Horizonte, in the area of Serra do Cipó National Park, in the middle of the Serra do Espinhaço Biosphere Reserve. In the rural areas of Conceição do Mato Dentro there are Quilombola communities, like the Candeias Community. So, the town is characterized by a special biodiversity and sociodiversity.

In 2006, the company Borbagato Agropastoril S.A arrived in the region claiming it wanted to buy land to raise horses. Later, it was found that the firm was a subsidiary of MMX, a mining company owned by the EBX Group. MMX was actually interested in starting a large iron ore project, which comprised, in addition to the mine, a $500 \mathrm{~km}$ pipeline and a port in São João da Barra (RJ). In 2008, MMX sold the project to Anglo American, a UK-based company. The implementation of the mine had various negative impacts on both environment and traditional communities in the region, including land grabbing, slave labor and water pollution.

First, there were many conflicts associated with the land purchasing process. In Conceição do Mato Dentro it was common that, after the death of a landowner, the sharing of the property among the heirs would not be made official. Alternatively, the family would communally manage the land. This traditional arrangement is known in the region 
as terra de bolo (aggregated land). However, it has been identified that, taking advantage of this situation, the company managed to buy the land from specific family members, without the consent of all the heirs, creating actual divisions within the families. After the deal was made, the company would forbid households to enter their properties and even close traditional community paths (Observatório dos Conflitos Ambientais de Minas Gerais 2013).

A second social issue related to the arrival of the mining activity was the emergence of slave labor in the region. In 2013, a company hired by Anglo American was denounced for hiring workers in conditions equivalents to slavery, including 100 Haitians. In the following year, the company was prosecuted for illegal outsourcing (Wrobleski 2014).

Lastly, there have been various problems associated with water pollution in Conceição do Mato Dentro. After the beginning of the mine operations, water in rivers and streams became improper for consumption. Farmers could not use water for watering their gardens and many animals died. In the Córrego do Passa Sete, which flows downstream from the tailings dam, many fish died, without a clear cause. Farmers associated the water pollution with mining activities; they had some technical support from social scientists, but none from natural scientists. As a result, they were not capable of producing "scientific" evidence that linked the water pollution to the mining activity. In the end, their claims were considered neither by government, nor by the company (Pedrosa and Ariadne 2014).

In spite of all these problems, Anglo American was granted the final environmental permit in 2014. Following, many environmental changes are still expected in the region. Understanding such changes, comprehending how they affect people's lives and helping them cope with such changes, also seem as opportunities for both natural and social scientists to foster sustainability.

\section{The Serra do Gandarela}

The Apolo Project has been one of the most controversial mining project in Minas Gerais. Vale S.A. intends to open an iron ore mine in the Serra do Gandarela region, a pristine area with high biodiversity and great potential for scientific research, environmental education and ecotourism (Lamounier et al. 2011). As Silva and Salgado (2009) argue, the preservation of the Serra do Gandarela is crucial because it summarizes, in a delimited area, the ecological complexity of the whole Quadrilátero Ferrífero.

The Serra do Gandarela is located in the centernortheast of the Quadrilátero Ferrífero, $65 \mathrm{~km}$ from Belo Horizonte. Its area comprises $467 \mathrm{~km}^{2}$, and covers six municipalities Barão de Cocais, Caeté, Itabirito, Raposos, Rio Acima and Santa Bárbara (Lamounier et al. 2011, Marent et al. 2011).

Environmental movements and local communities strongly oppose the project for various reasons, particularly its biodiversity and it hydraulic relevance.

In terms of biodiversity, there are various endangered species in the region, including the cougar (Puma concolor), the ocelot (Leopardus pardalis) and the maned wolf (Chrysocyon brachyurus) (Marent et al. 2011). In addition, the Serra do Gandarela concentrates $40 \%$ of the remaining canga area in the Quadrilátero Ferrífero. Canga is a type of vegetation with high levels of endemism that only occurs where soils are rich in iron (Lamounier et al. 2011). Cangas are very rare in Brazil, because mining activity has destroyed most areas. Because of the relationship between the vegetation and the iron concentration, this is a situation where ecosystem preservation and mining activities are mutually exclusive, and permitting 
mining necessarily destroys the canga ecosystem (Silva and Salgado 2009).

As far as water is concerned, the Serra do Gandarela region is one of the largest sources of underground water in the Quadrilátero Ferrífero and its rivers flow both into Rio das Velhas and Rio Doce basins (Lamounier et al. 2011). Locally, rivers from the Serra do Gandarela are responsible for the water supply of Caeté, Raposos and Rio Acima (Marent et al. 2011).

In spite of such ecological and social relevance, the area is threatened by an iron ore project that might last only 17 years. Due to the difficulty in obtaining the environmental license, there was an attempt to split the project into small parts and perform isolated EIAs. The main objective was to request a simplified license and avoid public hearings. The Office of the Public Prosecutor, though, demanded the project to be considered Class 6 (high impact), which made it more difficult for Vale S.A. to obtain the environment license (Marent et al. 2011).

As a strategy to restrict the impact of the Apolo project, local movements proposed the creation of a mosaic of protected areas. Depending on the current use of the territories, this mosaic would comprise a National Park, a Reserve for Sustainable Development and an Area of Relevant Ecological Interest (Lamounier et al. 2011). This mosaic was designed after intense dialogue between scientists from various areas, and community representatives. Crucial to the proposal was the Seminar "O olhar da UFMG sobre as serras do Gandarela e do Caraça: patrimônio sociambiental e sutentabilidade" (The UFMG understanding of the Gandarela and Caraça ranges: Socioenvironmental Heritage and Sustainability), in 2010. Apart from local organizations, the seminar involved geographers, geologists, biologists and political scientists. Scientists were also responsible for helping design the proposal to be presented to the Ministry of Environment.
Not only concerned with environmental preservation, but also with social and economic aspects, the Serra do Gandarela initiative also proposed programs for local development, taking into account existing economic activities. This proposal considered beekeeping and food production based on agroecological principles. In addition, it recommended the development of the region's touristic potential, due to the preserved natural environment, the various waterfalls and the several caves found in the area (Lamounier et al. 2011, Marent et al. 2011).

The Chico Mendes Institute for the Conservation of Biodiversity accepted the proposal for the National Park in 2012. Since then, the debate has focused on the park boundaries. Although it will not prevent the mine, it might save some of the cangas and allow local people to develop more sustainable economic activities.

\section{CONCLUSIONS}

In this paper, I argued that the quest to solve real problems is a plausible strategy to promote the dialogue between natural and social scientists. In addition, I indicated that, when trying to steer this dialogue towards sustainability issues, the evaluation of EIAs could be one of the key problems, as such assessments necessarily bring together social and environmental problems. In order to illustrate these arguments, I debated some of the environmental and social issues associated with open-pit mining and briefly described three case studies of conflicts associated with mining activities.

Along these lines, the first challenge I mentioned was stimulating the dialogue between natural and social scientists. This is not a simple task, as there are prejudices, misunderstandings and disagreements. In spite of these differences, commons aspects also exist, thus emphasizing the similarities between knowledge fields might be 
a first step to encourage "borrowings", research in fringe areas and, even the emergence of new disciplines.

The second and, probably, most difficult challenge consists in steering this dialogue towards sustainability. In order to do that, it is necessary to consider what kind of science is going to be developed. I propose that the quest for sustainability happens in the "real world"; therefore, any science that attempts to contribute to a more sustainable world must be able to communicate with society, create awareness and motivate change. Along these lines, studying social-environmental conflicts consists of not only understanding the environmental changes, but also in comprehending how people perceive these changes in their environment, and in helping them in avoiding or adapting to such changes. Therefore, these conflicts undoubtedly claim for the collaboration between social and natural scientists.

Lastly, the three case studies indicate high levels of inequality in the power relations between mining companies and communities. As the idea of sustainability undertakes equality as one of its main principles, I argue that, in order to move society towards sustainability, studies on EIAs or social-environmental conflicts must take into consideration the needs of the more vulnerable social groups and, whenever possible, incorporate their demands.

\section{RESUMO}

Neste artigo, eu argumento que a tentativa de solucionar problemas reais é uma possível estratégia para aproximar as ciências sociais e naturais, e sugiro que - como a Avaliação de Impacto Ambiental necessariamente aproxima aspectos ambientais e sociais - este debate é um forte candidato para esse tipo de tarefa. Este argumento é baseado em uma discussão geral sobre possibilidades e limitações da Avaliação de Impacto Ambiental, nos impactos socioambientais das atividades de mineração e em três estudos de caso. A análise dos casos indica possibilidades e limitações do diálogo entre cientistas de diferentes áreas - e da colaboração destes com movimentos sociais e comunidades afetadas - para evitar os impactos negativos de projetos de mineração e, eventualmente, aumentar sua sustentabilidade.

Palavras-chave: interdisciplinaridade, sustentabilidade, conflitos socioambientais, mineração.

\section{REFERENCES}

AMAZONAS MC. 2001. O que é a Economia Ecológica. Retrieved Dec 15, 2014; from http://www.ecoeco.org.br/. AXELROD R. 2008. Political science and beyond: presidential address to the American Political Science Association. Perspect Polit 6: 3-9.

Braga ALF, Pereira LAA, Procópio M, ANDrÉ PA AND SALDIVA PHDN. 2007. Associação entre poluição atmosférica e doenças respiratórias e cardiovasculares na cidade de Itabira, Minas Gerais, Brasil. Cad Saude Publica 23: S570-S578.

BRASIL. 2010. Inventário brasileiro de emissões antrópicas por fontes e remoções por sumidouros de gases de efeito estufa não controlados pelo Protocolo de Montreal. Brasília: Ministério de Ciência, Tecnologia e Inovação.

BROWN P. 1987. Popular Epidemiology revisited. Curr Sociol 45: $137-156$.

BÜHRS T. 2009. Environmental Integration: our common challenge. Albany: State University of New York, 276 p.

CAMPBELL LM. 2005. Overcoming obstacles to interdisciplinary research. Conserv Biol 19: 574-577.

CASHMORE M, RICHARDSON T, HILDING-RYEDVIK T AND EMMELIN L. 2010. Evaluating the effectiveness of impact assessment instruments: Theorising the nature and implications of their political constitution. Environ Impact Asses 30: 371-379.

COMMITTEE ON FACILITATING INTERDISCIPLINARY RESEARCH AND COMMITTEE ON SCIENCE ENGINEERING AND PUBLIC POLICY. 2004. Facilitating interdisciplinary research. Washington, D.C.: The National Academy Press

CORBURN J. 2005. Street Science: community knowledge and environmental health justice. Cambridge, MA: Massachusetts Institute of Technology, $281 \mathrm{p}$.

COSTANZA R, DALY HE AND BARTHOLOMEW JA. 1991. Goals, agenda and policy recommendations for ecological economics. In: Costanza R (Ed), Ecological economics: the science and management of sustainability. New York: Columbia University Press, $525 \mathrm{p}$.

DALY HE AND FARLEY J. 2004. Ecological economics: principles and applications. Washington, DC: Island Press, 454 p.

DIAMOND J. 2002. Evolution, consequences and future of plant and animal domestication. Nature 418: 700-707. 
EBISEMIJU FS. 1993. Environmental impact assessment: making it work in developing countries. J Environ Manage 38: $247-273$.

ELAW - ENVIRONMENTAL LAW ALLIANCE WORLDWIDE. 2010. Guidebook for evaluating mining project EIAs. Eugene, OR, $110 \mathrm{p}$.

FERrous RESOURCES DO BRASIL. 2012. Projeto de rede otimizada de monitoramento da qualidade do ar e meteorologia da região de Congonhas (RTC11045). Congonhas: Ferrous Resources do Brasil, 172 p.

FUNTOWICZ S, RAVETZ JR AND O'CONNOR M. 1998. Challenges in the use of science for sustainable development. Int J Sust Dev 1: 99-107.

Gerber JF, VEUthey S AND MARTINEZ-Alier J. 2009. Linking political ecology with ecological economics in tree plantation conflicts in Cameroon and Ecuador. Ecol Econ 68: 2885-2889.

GLASSON J AND SALVADOR NNB. 2000. EIA in Brazil - a procedures-practice gap. A comparative study with reference to the European Union, and especially the UK. Environ Impact Asses 20: 191-225.

GOULART V. 2014. Expansão da atividade mineradora em Congonhas (MG) pode agravar impactos ambientais no município. In: Fernandes FRC, Alamino RCJ and Araujo ER (Eds), Recursos minerais e comunidade: impactos humanos, socioambientais e econômicos (p. 245-248). Rio de Janeiro: CETEM, 392 p.

HANNIGAN J. 1995. Environmental sociology: a social constructionist perspective. Abingdon: Routledge, p. 271.

HOJE EM DIA. 2013. Profecia desagradável na histórica cidade de Congonhas. Hoje em Dia.

KALlis G, GómeZ-BAgGethun E AND Zografos C. 2013. To value or not to value? That is not the question. Ecol Econ 94: 97-105.

KIRCHHOFF D. 2006. Capacity building for EIA in Brazil: Preliminary considerations and problems to be overcome. J Environ Asses Pol Manage 8: 1-18.

LACH D. 2014. Challenges of interdisciplinary research: reconciling qualitative and quantitative methods for understanding human-landscape systems. Environ Manage 53: 88-93.

LAGUARDIA H. 2012. Questões ambientais barram CSN em Congonhas. Fato Relevante 3(34).

LAMOUNIER WL, CARVALHO VLM AND SALGADO AAR. 2011. Serra do Gandarela: possibilidade de ampliação das unidades de conservação no Quadrilátero Ferrífero-MG. Rev Dep Geo USP 22: 171-192.

LASCHEFSKI K. 2011. Estudo de caso: UHE Irapé e UHE Murta. In: FASE and IPPUR/UFRJ (Eds), Avaliação de Equidade Ambiental como instrumento de democratização dos procedimentos de avaliação de impacto de projetos de desenvolvimento. Rio de Janeiro: Federação de Órgãos para Assistência Social e Educacional; Instituto de Pesquisa e
Planejamento Urbano e Regional da Universidade Federal do Rio de Janeiro.

LEFF E. 2011. Complexidade, interdisciplinaridade e saber ambiental 14: 309-335.

LEROY JP AND ACSELRAD H. 2009. Por avaliações sócioambientais rigorosas e responsáveis dos empreendimentos que impactam o território e as populações. Rio de Janeiro: FASE; IPPUR/UFRJ.

M'GONIGLE RM. 1999. Ecological economics and political ecology: towards a necessary synthesis. Ecol Econ 28: 1126.

Malerba J. 2014. Apresentação. Áreas livres de mineração: por que e para quê? In: Malerba J (Ed), Diferentes formas de dizer não: experiências internacionais de resistência, restrição e proibição ao extrativismo mineral. Rio de Janeiro: Fase, 160 p.

MARENT BR, LAMOUNIER WL AND GONTIJO BM. 2011. Conflitos ambientais na Serra do Gandarela, Quadrilátero Ferrífero - MG: mineração x preservação. Geografias 7: 99-113.

MARTINEZ-ALIER J. 2002. The environmentalism of the poor: a study of ecological conflicts and valuation. Cheltenham: Edward Elgar Pub, 328 p.

Milanez B, Chammas D, Bossi D, Malerba J And CASTURINO M. 2010. Impactos da mineração. Le Monde Diplomatique Brasil, p. 34.

MOREIRA IVD. 1985. Avaliação de Impacto Ambiental - AIA. Rio de Janeiro: FEEMA.

MORRISON-SAUNDERS A AND EARLY G. 2008. What is necessary to ensure natural justice in environmental impact assessment decision-making? Impact Asses Proj App 26: 29-42.

O'Faircheallaigh C. 2010. Public participation and environmental impact assessment: Purposes, implications, and lessons for public policy making. Environ Impact Asses 30: 19-27.

OBSERVATÓRIO DOS CONFLITOS AMBIENTAIS DE MINAS GERAIS. 2013. Resistência à mineração da Anglo Ferrous Minas-Rio S.A. em Conceição do Mato Dentro. Retrieved Dec 21, 2014; from http://conflitosambientaismg.lcc. ufmg.br/conflito/?id=549.

PEDROSA AP AND ARIADNE Q. 2014. Mesmo com alertas da UFMG e MPF, Ibama libera mineroduto. O Tempo.

POWER TM. 2002. Digging to development? A historical look at mining and economic development. Boston, MA: Oxfam America.

RBJA - REDE BRASILEIRA DE JustiÇA AMBIEnTAL. 2009. Boletim Justiça Ambiental ( ${ }^{\circ}$ 4). Rio de Janeiro.

RICHARDSON T. 2005. Environmental assessment and planning theory: four short stories about power, multiple rationality and ethics. Environ Impact Asses 25: 341-365.

ROCHA EC, CANTO JL AND PEREIRA PC. 2005. Avaliação de impactos ambientais nos países do Mercosul. Ambient Soc 8: $147-160$. 
ROHDE GM. 2006. Estudos de impacto ambiental: a situação brasileira em 2000 RIMA. Relatório de Impacto Ambiental. Legislação, elaboração e resultados. Porto Alegre: Editora da UFRGS, p. 43-63.

SAKAMOTO L. 2010. Justiça do Trabalho condena Vale a pagar R\$ 300 milhões. Retrieved Dec 19, 2014; from http://blogdosakamoto.blogosfera.uol.com.br/2010/03/10/ justica-do-trabalho-condena-vale-a-pagar-r-300-milhoes/.

SANCHEZ LE. 2006. Avaliação de impacto ambiental: conceitos e métodos. São Paulo: Oficina de Textos, 584 p.

SCHNELLRATH J, MONTE MBDM, SAMPAIO JA, CUZZUOL JR, PEREIRA AMG AND PINTO AFDM. 2002. Ferro - Mina Fábrica - FERTECO. Comunicação técnica elaborada para o livro Usina de beneficiamento de minérios do Brasil. Rio de Janeiro: CETEM, 14 p.
SILVA JR AND SALGADO AAR. 2009. Mapeamento das unidades de relevo da região da Serra do Gandarela Quadrilátero Ferrífero/MG. Geografias 5: 107-125.

TROW M. 1957. Comment on participant observation and interviewing: a comparison. Hum Organ 16: 33-35.

VANCLAY F. 2003. International principles for social impact assessment. Impact Asses Proj App 21: 5-11.

WROBLESKI S. 2014. Fiscalização volta a flagrar escravidão em megaobra da Anglo American. Repórter Brasil. Retrieved Dec 21, 2014; from http://reporterbrasil.org. br/2014/05/fiscalizacao-volta-a-flagrar-escravidao-emmegaobra-da-anglo-american/.

ZHOURI A. 2008. Justiça ambiental, diversidade cultural e accountability: desafios para a governança ambiental. Rev Bras Ci Soc 23: 97-107. 